\title{
Plate Settlement: Determination of Fouling Organisms in Brunei
}

\author{
Hjh Zuliza Hj Jolkifli1,* and Ranimah H.A. Wahab1,,* \\ ${ }^{1}$ Capture Fisheries Development Division Department of Fisheries, Ministry of Industry and Primary Resources, Brunei Darussalam \\ *Corresponding authors: zuliza.jol@gmail.com; ranimah.wahab@fisheries.gov.bn
}

\author{
KEYWORDS \\ Alien \\ Biological invasion, \\ CPCe \\ Fouling \\ Invasive taxa \\ Species
}

\begin{abstract}
Shipping is considered a primary vector of biological invasion. Hull fouling is recognized as one of the common vectors involved in the translocation of marine pests that may have deleterious impacts to ecology and economy. In an effort to understand the fouling communities within Brunei waters and as an early attempt to obtain baseline data, PVC plates were deployed at a depth of $1 \mathrm{~m}$, checked for taxa composition and replaced with new plates monthly and quarterly over a period of one year. The Caribbean bivalve Mytilopsis sallei was absent throughout the period of study, and plates were mainly colonized by native fouling species and silt. Nevertheless, further verification on the absence of Invasive Alien Species (IAS) is still required. This study summarizes the improved methods of analysis for better control and management in order to impede the incursion or invasion of undesirable species.
\end{abstract}

(c) The Author(s) 2018. This article is distributed under a Creative Commons Attribution-ShareAlike 4.0 International license.

\section{INTRODUCTION}

In recent years, increasing attention has been directed towards the issue of the breakdown of major biogeographic barriers as a consequence of biological invasions in natural marine communities (Mooney \& Hobbs 2000). Deleterious ecological impacts of biological invasion include competition and predation upon native species that potentially alter natural habitats and in extreme cases cause local extinctions (Raaymakers 2002). Irreversible and increasing severity over time of biological invasion is an important feature as occurred in Monaco, where since the first recorded appearance of invasive green alga Caulerpa taxifolia, the species has covered $97 \%$ of available surfaces in Toulon and Genoa, and this Indo-Pacific species was projected to spread across the Mediterranean Sea (Bax et al. 2003).

Anthropogenic influences have of course been defined as an active and dynamic process in passive dispersal of invasive alien species (IAS). Only in this era of environmental awareness, monitoring of IAS has become a primary consideration and researchers has heightened case studies of a particular anthropogenic mode, maritime vessel hull fouling (Minchin et al. 2009). Translocation of marine organisms from discharge of ballast water is claimed to be the dominant vector, but the effect of biofouling is poorly quantified. Drake \& Lodge (2007) showed that the marine growth on the hull of a bulk carrier comprised of 100 to 200 fouling species, therefore invasion risk of biofouling may be comparable or exceed that of ballast water.

Currently, Brunei is considered to be in a position of great concern due to the lack of knowledge concerning organisms associated with the hulls of vessels entering coastal waters. Historical interest in marine invasion is also relatively low. This paper is intended as an introduction to the field of marine invasion and serves as a baseline survey of Brunei Bay to establish the identity of the natural inhabitants. With the familiarisation of existing natural biodiversity, new recruitment to the area can then be identified to fill gaps at the intersection of science and policy that impede IAS management.

\section{MATERIALS AND METHODS}

This project involves with the monitoring the transferred of invasive organisms by shipping. Muara port is the only deepwater port and hub port available in Brunei. Therefore, survey of hull fouling had been carried out at this area only.

Located approximately $29 \mathrm{~km}$ from the country's capital Bandar Seri Begawan, Muara port is the main gateway for foreign goods coming into Brunei Darussalam, and for the export of local produce. Being recognized as a high-tech deep-water port, it is currently being established as the centre of maritime activity for people in Brunei, Indonesia, Malaysia and the Philippines.

Three sets of panels, namely monthly, quarterly and 1year panels, based on the duration of residence time in the water, were deployed at the selected site (Figure 1) for the sampling of marine fouling community. PVC settling plates (3 replicates for each set) were fully submerged in vertical position, approximately $1 \mathrm{~m}$ depth below the water surface (Table 1). Upon retrieval, both sides of each plate were photographed using digital camera for analysis of fouling community.

\section{RESULTS}

During the last 12 months (April 2012 to April 2013) of the programme, the deployment periods of the settlement plates were not consistent. As a result, not all samples collected were quantitatively analysed. however, all collected plates were photographed. 


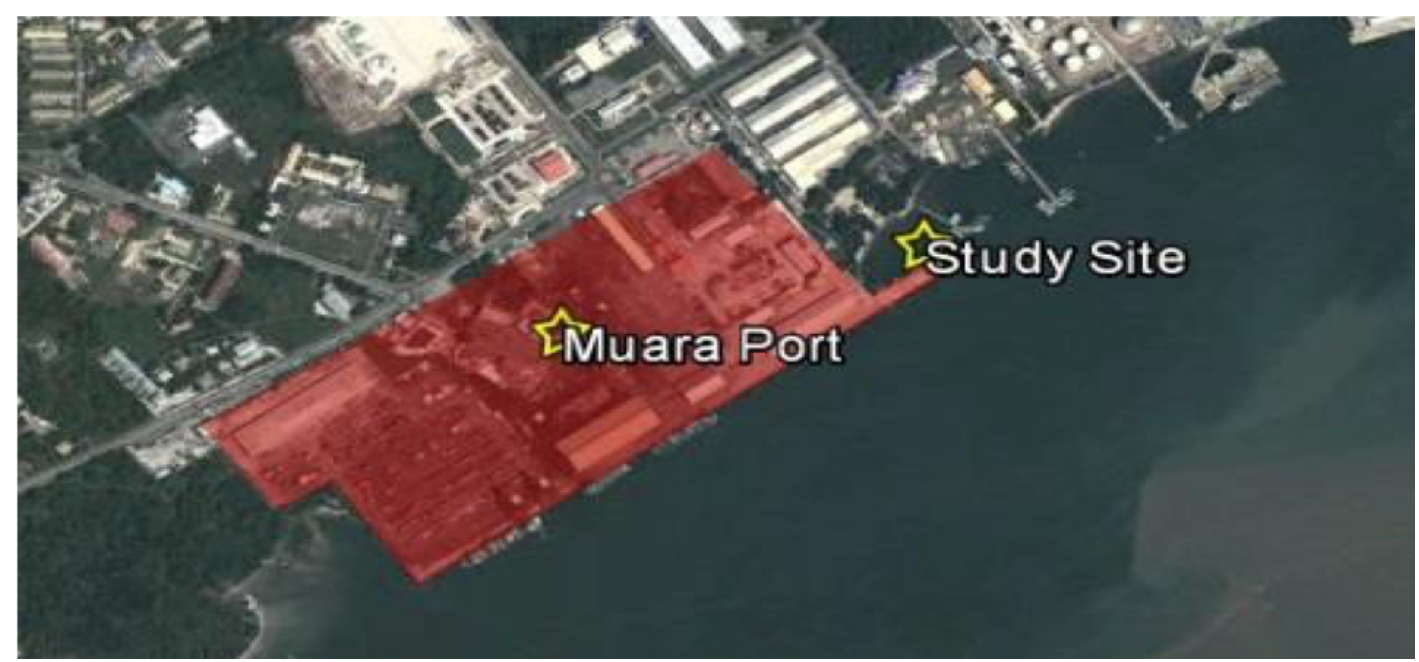

Figure 1. Location of study site (Latitude: $5^{\circ} 1^{\prime} 39.40^{\prime \prime} \mathrm{N}$; Longitude: $115^{\circ} 4^{\prime} 31.98 \mathrm{E}$ ) at Muara Port, Brunei Darussalam.

\subsection{Monthly plates}

Figure 2 shows the average distribution of fouling organisms on the retrieved plates, which were mainly coated with silt and slime, and the sedentary organisms settled on the plates were species mainly belonging to phyla Arthropoda, Annelida, Bryozoa, Cnidaria, Mollusca, Porifera and Urochordata (in alphabetical order).

The monthly settlement of biofoulers was not uniform (Table 2). Considerable variation was observed throughout the one-year immersion period. The densities of barnacles (phylum Arthropoda) and tubeworms (phylum Annelida) were not uniform and both reached their peak densities in March 2013. Settlement of soft cnidarians and bryozoans was also significantly high $(p<0.05)$ in February 2013. Meanwhile, sponges (phylum Porifera) heavily covered the plate retrieved in June 2012.

\subsection{Quarterly plates}

Figure 3 shows the mean frequency of occurrence of each fouling taxonomic group covering the retrieved settlement plates. The dominant fouling group at the study site was the barnacles with a significant maximum frequency of occurrence in April 2013. However, there was significant variation $(p<0.05)$ in frequency of occurrence for certain taxonomic groups: Cnidarians (Soft), Bryozoa, and Mollusca, across the sampling period. The mean occurrence of cnidarians was highest in the month of July 2012 whereas both Bryozoa and Mollusca occurred at their highest frequencies in November 2012.

\subsection{Yearly plates}

All common fouling taxonomic groups were presented on settlement plates (Figure 4, 5). Molluscs, barnacles and bryozoans were the dominant fouling groups with maximum frequency of occurrence of $31 \%, 22 \%$ and $13 \%$ respectively. Annelida only covered $4 \%$ of the surface of settlement plates (Appendix A1-3).

\subsection{Observations of invasive alien species}

Due to taxonomic difficulties and the lack of local expertise, species names for many taxonomic groups have not been confirmed. However, the Caribbean alien bi-

Table 1. Chronology of PVC settlement plate collection at Muara Bay, Brunei Darussalam.

\begin{tabular}{|c|c|c|c|c|c|}
\hline \multicolumn{3}{|c|}{ Retrieval date } & \multirow[t]{2}{*}{ Plates collected? } & \multirow[t]{2}{*}{ Duration in water } & \multirow[t]{2}{*}{ Analysis } \\
\hline Year & Month & Day & & & \\
\hline \multirow[t]{10}{*}{2012} & May & 28 & Yes & 1 month & Plates collected and photographed \\
\hline & June & 27 & Yes & 1 month & Plates collected and photographed \\
\hline & July & 28 & Yes & 1 month & Plates collected and photographed \\
\hline & July & - & No & 3 months & None-plates were lost \\
\hline & August & - & No & 1 month & None-plates were lost \\
\hline & September & 29 & Yes & 1 month & Plates collected and photographed \\
\hline & October & 30 & Yes & 1 month & Plates collected and photographed \\
\hline & November & 29 & Yes & 1 month & Plates collected and photographed \\
\hline & November & 29 & Yes & 3 months & Plates collected and photographed \\
\hline & December & 29 & Yes & 1 month & Plates collected and photographed \\
\hline \multirow[t]{7}{*}{2013} & January & 29 & Yes & 1 month & Plates collected and photographed \\
\hline & January & 29 & No & 3 months & None -plates were lost \\
\hline & February & 28 & Yes & 1 month & Plates collected and photographed \\
\hline & March & 30 & Yes & 1 month & Platescollected and photographed \\
\hline & April & 30 & Yes & 1 month & Plates collected and photographed \\
\hline & April & 30 & Yes & 3 months & Plates collected and photographed \\
\hline & April & 30 & Yes & 1 year & Plates collected and photographed \\
\hline
\end{tabular}




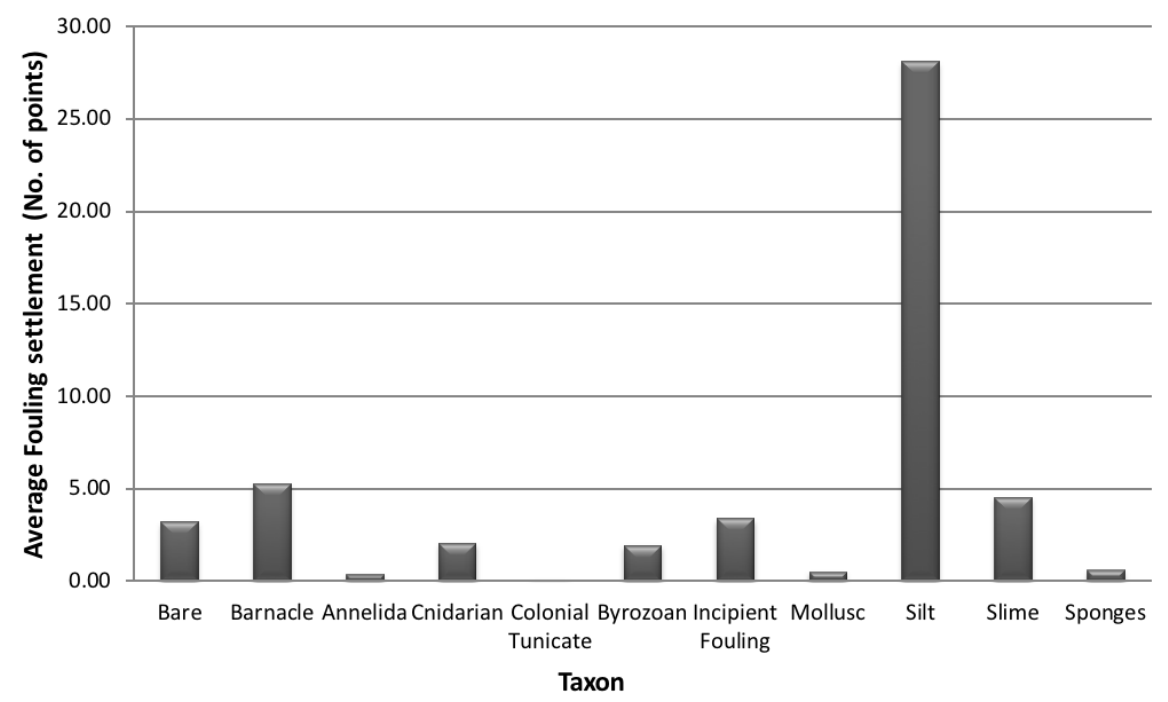

Figure 2. Mean percentage cover of each scored category for 1-month old settlement plates from April 2012 to March 2013 in Muara Port, Brunei Darussalam.

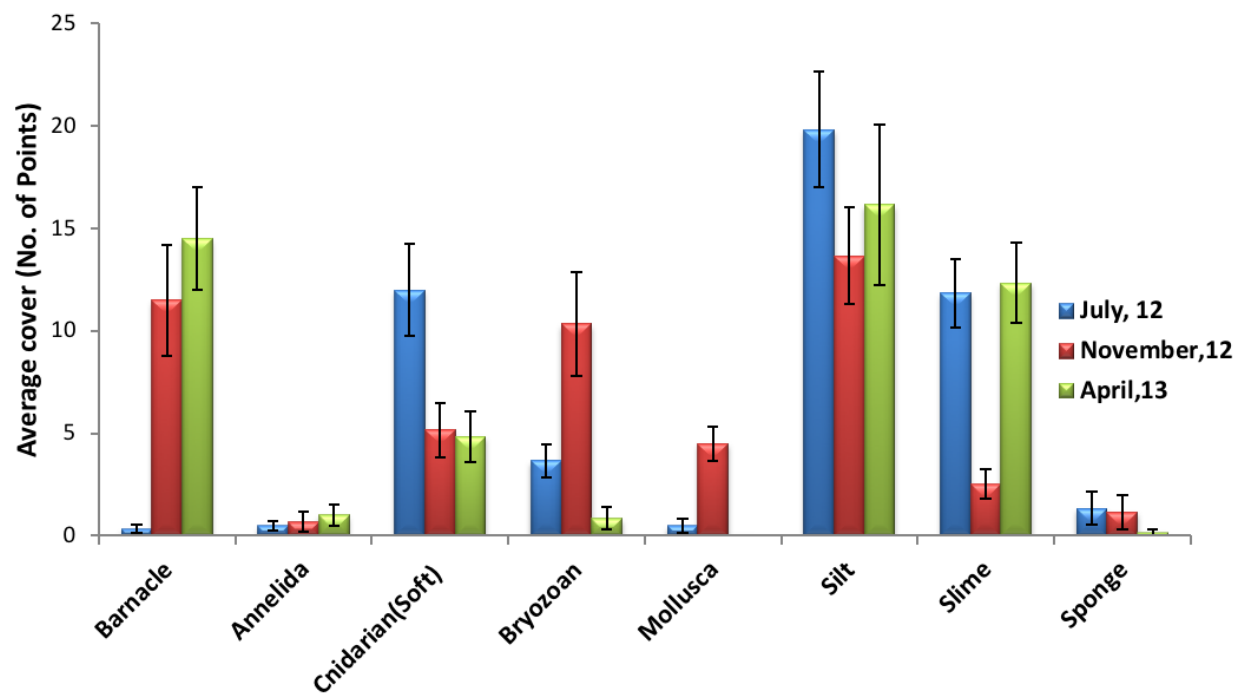

Figure 3. Mean percentage cover of each scored category for 3-month old settlement plates in July 2012 , November 2012 and April 2013 at Muara Port, Brunei Darussalam.

valve Mytilopsis sallei was not observed on the settlement plates retrieved from the study site for monthly, quarterly and 1-year plates. Fouling organisms settled on all the plates are comprised of Balanus sp., Saccostrea sp., Modiolus sp. and local Triphyllozoon sp. which are native to tropical Brunei waters. There is low diversity of taxonomic groups fouling the settlement plates and the fouling groups coating the PVC frame were similar to those covering the settlement plates.

\section{DISCUSSION}

In view of increasing naval activities, there is a growing concern on the rapid alteration of species diversity en- demic to the harbour. The study was undertaken to collect baseline information on the current fouling organisms. This will allow us to analyse the extent of intrusion of invasive alien species and to recognize any changes in species richness in relation to the seasonal variations.

\subsection{Existence of invasive alien species?}

The present study revealed that the bio-fouling present on the plates appeared to be only dominated by native species of barnacles, cnidarians and bryozoans, and the settlement each of these groups was directly proportional to the duration of residence time in the water. DePalma (1984) stated

Table 2. Statistical analysis of the bio-foulers near Muara port: monthly differences in percentage cover. S = significant; NS = not significant.

\begin{tabular}{lcccccccc}
\hline & $\begin{array}{c}\text { Arthropoda } \\
\text { (Barnacle) }\end{array}$ & Annelida & Cnidarian & $\begin{array}{c}\text { Colonial } \\
\text { Tunicate }\end{array}$ & Byrozoan & $\begin{array}{c}\text { Incipient } \\
\text { Fouling }\end{array}$ & $\begin{array}{c}\text { Mollusca } \\
\text { Porifera } \\
\text { (Sponge) }\end{array}$ \\
\hline P-value & 0.0057 & $5.24 \mathrm{e}^{-05}$ & $2.339 \mathrm{e}^{-15}$ & 0.45 & $3.059 \mathrm{e}^{-07}$ & 0.56 & 0.06057 & $3.151 \mathrm{e}^{-08}$ \\
Significance & $\mathrm{S}$ & $\mathrm{S}$ & $\mathrm{S}$ & $\mathrm{NS}$ & $\mathrm{S}$ & $\mathrm{NS}$ & $\mathrm{NS}$ & $\mathrm{S}$ \\
\hline
\end{tabular}




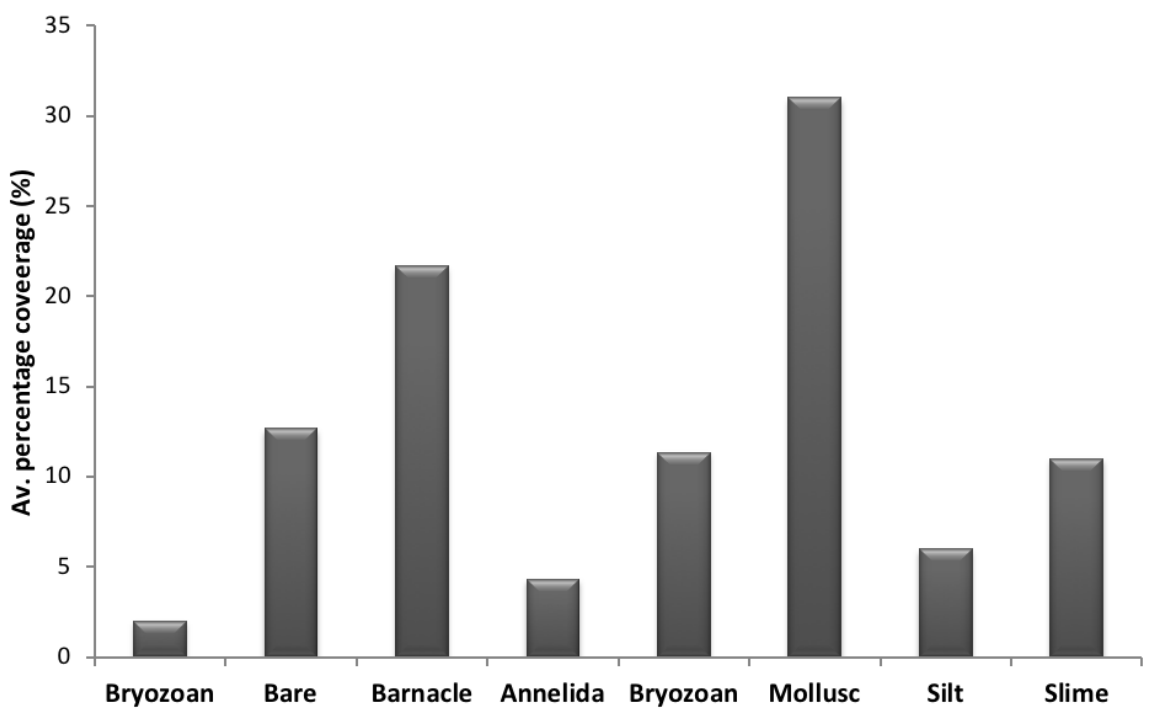

Figure 4. Mean percentage cover of each scored category on PVC settlement plates after one year of immersion in Muara Port, Brunei Darussalam.

that to study the bio-fouling in the marine environment, density or population abundance is a reliable parameter. Based on the preliminary data collected from this study, IAS in Brunei waters appears to be absent so far, but preventative measures are still applicable. With the natural fouling communities that occur, it is assumed that the data obtained from the sampling site are representative of the range of organisms that foul hard substrata at Serasa Bay immediately south of Muara Port. However, the mass areas of settlement plates left un-fouled showed the significance on the absence of IAS is in need of further verification especially with the realization on a number of introduce errors in this experimental method.

\subsection{Temporal variation}

Referring to the analysis result, it is an effortful attempt to make any inferences regarding temporal trends in the distribution of taxonomic groups upon the settlement plates. Majority of the area on the settlement plate tended to be un-fouled as they were either covered with silt or bare space. Environmental fluctuations in Serasa Bay mav be the possible cue for the lack of settlement bv fouling organisms upon the settlement plates. A previous survey conducted within this Bay (Chua et al. 1987) defined the water as partially stratified with wide range of current speed at the surface $(5-29 \mathrm{~cm} / \mathrm{s})$ and bottom (4-39 cm/s). Swami \& Uddhayakumar (2008) stated that stable hydrographical conditions have a critical influence on species richness thus resulting in seasonal variation on settlement patterns.

\subsection{Sampling error}

The non-existence of IAS and the sporadic nature of certain taxonomic groups found on the settlement plates may be as a consequence of true temporal variability or alternatively, an error resulting from the sampling technique. Possible errors may have occurred as a result of the collector plates distantly positioned from the Muara port. Due to the placement of the settlement plates, the derived estimation of percentage coverage could be an incomplete representation of fouling communities. The importance of proximity to harbours/ports was highlighted in the report by Labowitch et al. (2006). Their study in tropical northern Australia indicated that sDatial variation has an inevitable

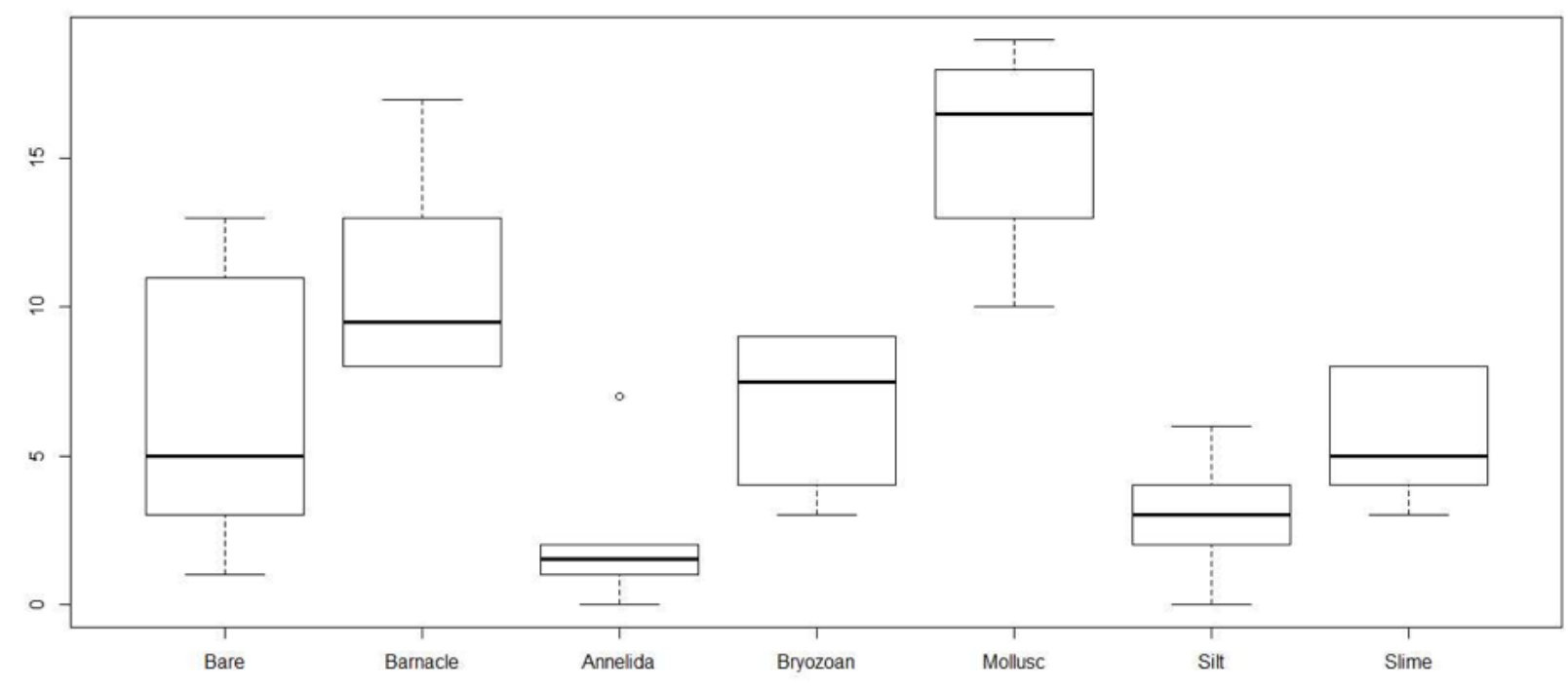

Figure 5. Boxplot of the frequency of occurrence of each scored category recorded for the 1 - year settlement plates in Muara Port, Brunei Darussalam. 
influence on data collection, and multiple deployment sites are required to attain a good knowledge of fouling organisms present at any one area. Labowitch et al. (2006) recognition on the site selection for deployment of settlement locator was emphasized again in another study, which involved positioning of collectors at Raffles Bay in the Cobourg Peninsula, Australia. Due to its close proximity to the location of the incoming vessels, total wet biomass recorded from the settlement plates and the abundance of tubiculous amphipods on the settlement plates deployed at Raffles Bay were an order of magnitude higher than at other monitoring sites around the Northern Territory.

The relative abundance of each taxonomic group is collected by methods described in this report. This method (using PVC plates) negated on the influence of substratum rugosity on fouling settlement, composition, and diversity. The species composition during the early quarter of this sampling was significantly lower than that of later period, and substratum rugosity may be the possible attributing factor. Ompi (2010) attributed the variation of settlement of mytilid larvae to different substratum cues in which the larvae preferentially settled on roughness or scarred surfaces, resulting in rare records of settlers on smooth PVC surfaces.

Independency of fouling recruitment on the position of the collector plates in the water column is the primary assumption applied for this experimental design. Hanson and Bell (1975) reported that both intertidal and subtidal marine fouling components showed distinct vertical patterns in the fouling of test plates. Vertical distribution of marine fouling organisms is significant when the sampling site located in close proximity to the shore in relatively shallow water with prevailing alteration of water flow (Ramsay et al. 2009). Future studies could deploy collectors that sample the entire water column for better representative samples.

Invasive alien species can endanger native biodiversity and threaten the ecological integrity of natural coastal ecosystems. Based on the present study, Brunei is currently free from known marine invasive species in contrast to many ports and harbours. Brunei Darussalam is currently undergoing expansion in many industries that involved impending increases in maritime traffic and further development of the aquaculture industry along the coastline. Recognising shipping and aquaculture industries as marine pest vectors, the Department of Fisheries will continue to monitor the Brunei coastline for the introduction of introduced species dispersed outside their natural range that can potentially impact the native biodiversity at the genetic, population, ecosystem and economic levels.

\section{RECOMMENDATIONS}

Despite the absence of IAS, shipping is undoubtedly; serve as both primary and secondary vectors for the transfer of non-indigenous marine species through ballast water and biofouling of vessels. Even though Muara port activities are not intense, the insufficiency of existing legal mechanism to regulate all aspects of the biofouling problem encourages the development of national strategies and plans for responding to potential threats. Guidelines to address biofouling at international level and analysis options have now been included on the work programme of the International Maritime Organisation (IMO-GloFouling). The IMO or other international forums could be used to develop non-mandatory international standards in the form of recommendations and non-binding resolutions to provide a basis for harmonisation of such measures.

- Routine vessel monitoring to document the risk of species invasions by hull fouling;

- Identification of vessels which are likely to carry high risk species in their hull fouling (risk assessment);

- Evaluate hull treatment methods for vessels;

- Increase awareness amongst dockyard and scrap yard operators that organisms removed from ship hulls should be collected and discharged safely on land; and

- Strongly encourage marina operators to apply IMO guidelines.

\section{REFERENCES}

Bax N, Williamson A, Aguero M, Gonzalez E, Geeves W. 2003. Marine invasive alien species: a threat to global biodiversity. Marine Policy 27:313-323.

Chua TE, Chou LM, Sadorra MSM, editors. 1987. The coastal environmental profile of Brunei Darussalam: resource assessment and management issues. Manila: Fisheries Department, Ministry of Development, Brunei Darussalam and International Center for Living Aquatic Resources Management. ICLARM Technical Reports 18.

DePalma JR. 1984. Fouling production in the World Ocean. In: Garsi D, editor. Proceedings of $6^{\text {th }}$ International Congress on Marine Corrosion and Fouling; Athens, Greece. p. 237-244.

Drake JM, Lodge DM. 2007. Hull fouling is a risk factor for intercontinental species exchange in aquatic ecosystems. Aquatic Invasions 2:121-131.

Hanson CH, Bell J. 1975. Subtidal and intertidal marine fouling on artificial substrata in Northern Puget Sound, Washington. Fisheries Bulletin 74:377-385.

Labowitch SB, Cribb HN, Marshall AJ. 2006. Monitoring for marine pests at Garden Point, Melville Island between October 2004 and September 2006. Annual report for Great Southern Plantations Pty Ltd. Darwin: Department of Primary Industry, Fisheries and Mines, Northern Territory Government, Australia.

Minchin D, Gollasch S, Cohen AN, Hewitt CL, Olenin S. 2009. Characterizing vectors of marine invasion. Biological Invasions in Marine Ecosystems 204:109-116.

Mooney HA, Hobbs RJ. 2000. Invasive species in a changing world. Washington DC: Island Press.

Ompi M. 2010. Settlement behaviour and size of mussel larvae from the family Mytilidae (Brachidontes erosus (Lamarck, 1819), Brachidontes rostratus (Dunker, 1857), Trichomya hirsutus (Lamarck, 1819), and Mytilus galloprovincialis Lamarck, 1819). Journal of Coastal Development 13:215-227.

Raaymakers S. 2002. The ballast water problem: global ecological, economic and human health impacts. Paper presented at: RECSO/IMO Joint Seminar on Tanker Ballast Water Management \& Technologies; 2002 Dec 16-18; Dubai, UAE.

Ramsay A, Davidson J, Bourque D, Stryhn H. 2009. Recruitment patterns and population development of the invasive ascidian Ciona intestinalis in Prince Edward Island, Canada. Aquatic Invasions 4:169-176.

Swami BS, Udhyakumar M. 2008. Seasonal influence on settlement, distribution and diversity of fouling organisms at Mumbai Harbour. Indian Journal of Marine Sciences 39:57-67. 
Appendix A1. Fouling community composition in quarterly panels at Muara Port, Brunei Darussalam. Mean total cover \pm standard error, by major fouling taxa.

\begin{tabular}{|c|c|c|c|c|c|c|c|c|c|}
\hline \multicolumn{2}{|c|}{ Quarterly Panel } & \multirow{2}{*}{$\begin{array}{c}\text { Barnacle } \\
0.33\end{array}$} & \multirow{2}{*}{$\begin{array}{c}\text { Annelida } \\
0.50\end{array}$} & \multirow{2}{*}{$\begin{array}{c}\begin{array}{c}\text { Cnidarian } \\
\text { (Soft) }\end{array} \\
12.00\end{array}$} & \multirow{2}{*}{$\begin{array}{c}\text { Bryozoan } \\
3.67\end{array}$} & \multirow{2}{*}{$\begin{array}{c}\text { Mollusc } \\
0.50\end{array}$} & \multirow{2}{*}{$\begin{array}{c}\text { Silt } \\
19.83\end{array}$} & \multirow{2}{*}{$\begin{array}{l}\text { Slime } \\
11.83\end{array}$} & \multirow{2}{*}{$\begin{array}{c}\text { Sponge } \\
1.33\end{array}$} \\
\hline July, 12 & Mean & & & & & & & & \\
\hline & SE & 0.21 & 0.22 & 2.25 & 0.80 & 0.34 & 2.82 & 1.68 & 0.80 \\
\hline \multirow[t]{2}{*}{ Nov, 12} & Mean & 11.50 & 0.67 & 5.17 & 10.33 & 4.50 & 13.67 & 2.50 & 1.17 \\
\hline & SE & 2.70 & 0.49 & 1.33 & 2.53 & 0.85 & 2.38 & 0.72 & 0.83 \\
\hline \multirow[t]{2}{*}{ April, 13} & Mean & 14.50 & 1.00 & 4.83 & 0.83 & 0.00 & 16.17 & 12.33 & 0.17 \\
\hline & SE & 2.51 & 0.52 & 1.22 & 0.54 & 0.00 & 3.93 & 1.96 & 0.17 \\
\hline
\end{tabular}

Appendix A2. Fouling community composition in monthly panels at Muara Port, Brunei Darussalam. Mean total cover \pm standard error, by major fouling taxa.

\begin{tabular}{|c|c|c|c|c|c|c|c|c|c|c|c|c|}
\hline \multicolumn{2}{|c|}{ Monthly Panel } & \multirow{2}{*}{$\begin{array}{l}\text { Bare } \\
0.67\end{array}$} & \multirow{2}{*}{$\begin{array}{c}\text { Barnacle } \\
5.33\end{array}$} & \multirow{2}{*}{$\begin{array}{c}\text { Annelida } \\
0.00\end{array}$} & \multirow{2}{*}{$\begin{array}{c}\begin{array}{c}\text { Cnidarian } \\
\text { (Soft) }\end{array} \\
0.00\end{array}$} & \multirow{2}{*}{$\begin{array}{c}\begin{array}{c}\text { Colonial } \\
\text { Tunicate }\end{array} \\
0.00\end{array}$} & \multirow{2}{*}{$\begin{array}{c}\text { Bryozoans } \\
0.00\end{array}$} & \multirow{2}{*}{$\begin{array}{c}\begin{array}{c}\text { Incipient } \\
\text { Fouling }\end{array} \\
7.17\end{array}$} & \multirow{2}{*}{$\begin{array}{c}\text { Mollusc } \\
0.00\end{array}$} & \multirow{2}{*}{$\begin{array}{c}\text { Silt } \\
29.67\end{array}$} & \multirow{2}{*}{$\begin{array}{l}\text { Slime } \\
6.50\end{array}$} & \multirow{2}{*}{$\begin{array}{c}\text { Sponge } \\
0.67\end{array}$} \\
\hline May, 12 & Mean & & & & & & & & & & & \\
\hline & SE & 0.45 & 2.23 & 0.00 & 0.00 & 0.00 & 0.00 & 1.04 & 0.00 & 3.06 & 1.88 & 0.61 \\
\hline \multirow[t]{2}{*}{ Jun, 12} & Mean & 0.17 & 1.17 & 0.00 & 0.00 & 0.00 & 3.83 & 2.00 & 0.83 & 20.50 & 18.83 & 2.67 \\
\hline & SE & 0.17 & 0.83 & 0.00 & 0.00 & 0.00 & 1.01 & 1.26 & 0.65 & 2.13 & 2.70 & 0.88 \\
\hline \multirow[t]{2}{*}{ July, 12} & Mean & 0.33 & 2.83 & 0.00 & 5.33 & 0.33 & 0.50 & 1.33 & 0.17 & 29.67 & 8.33 & 1.00 \\
\hline & SE & 0.33 & 0.91 & 0.00 & 1.41 & 0.33 & 0.22 & 0.88 & 0.17 & 1.84 & 1.15 & 0.37 \\
\hline \multirow[t]{2}{*}{ Sept, 12} & Mean & 1.17 & 2.33 & 0.17 & 0.83 & 0.00 & 4.17 & 8.00 & 0.83 & 27.83 & 3.50 & 1.17 \\
\hline & SE & 0.60 & 0.76 & 0.17 & 0.83 & 0.00 & 2.26 & 3.44 & 0.54 & 2.89 & 1.54 & 0.60 \\
\hline \multirow[t]{2}{*}{ Oct, 12} & Mean & 0.33 & 7.17 & 0.17 & 0.00 & 0.00 & 0.67 & 13.33 & 0.67 & 26.67 & 0.67 & 0.17 \\
\hline & SE & 0.33 & 2.29 & 0.17 & 0.00 & 0.00 & 0.42 & 2.40 & 0.33 & 4.47 & 0.49 & 0.17 \\
\hline \multirow[t]{2}{*}{ Nov, 12} & Mean & 1.33 & 5.67 & 0.33 & 0.00 & 0.00 & 0.33 & 0.17 & 1.67 & 40.50 & 0.00 & 0.00 \\
\hline & SE & 0.88 & 1.31 & 0.21 & 0.00 & 0.00 & 0.21 & 0.17 & 0.49 & 2.05 & 0.00 & 0.00 \\
\hline \multirow[t]{2}{*}{ Dec, 12} & Mean & 17.83 & 7.17 & 0.00 & 0.00 & 0.00 & 0.67 & 0.50 & 0.50 & 23.17 & 0.00 & 0.17 \\
\hline & SE & 5.78 & 1.82 & 0.00 & 0.00 & 0.00 & 0.33 & 0.50 & 0.34 & 3.66 & 0.00 & 0.17 \\
\hline \multirow[t]{2}{*}{ Jan, 13} & Mean & 3.00 & 4.17 & 0.50 & 1.17 & 0.00 & 1.33 & 3.17 & 0.17 & 32.17 & 4.33 & 0.00 \\
\hline & SE & 0.89 & 0.87 & 0.22 & 0.48 & 0.00 & 0.56 & 0.40 & 0.17 & 1.62 & 1.41 & 0.00 \\
\hline \multirow[t]{2}{*}{ Feb, 13} & Mean & 0.17 & 6.33 & 0.17 & 12.67 & 0.00 & 8.33 & 0.33 & 0.00 & 14.33 & 7.00 & 0.67 \\
\hline & SE & 0.17 & 2.35 & 0.17 & 2.09 & 0.00 & 1.69 & 0.21 & 0.00 & 3.64 & 1.00 & 0.49 \\
\hline \multirow[t]{2}{*}{ Mar, 13} & Mean & 9.50 & 11.50 & 2.00 & 2.17 & 0.00 & 1.17 & 0.83 & 0.17 & 22.33 & 0.67 & 0.00 \\
\hline & SE & 3.14 & 2.20 & 0.63 & 0.65 & 0.00 & 0.31 & 0.40 & 0.17 & 1.98 & 0.42 & 0.00 \\
\hline \multirow[t]{2}{*}{ Apr, 13} & Mean & 0.83 & 4.50 & 0.83 & 0.50 & 0.00 & 0.17 & 0.50 & 0.50 & 42.17 & 0.00 & 0.00 \\
\hline & SE & 0.83 & 1.12 & 0.48 & 0.34 & 0.00 & 0.17 & 0.34 & 0.34 & 1.60 & 0.00 & 0.00 \\
\hline
\end{tabular}

Appendix A3. Fouling community composition in yearly panels at Muara Port, Brunei Darussalam. Mean total cover \pm standard error, by major fouling taxa. (1-year panel; number on the frequency of occurrence of each taxonomic group recorded.)

\begin{tabular}{|c|c|c|c|c|c|c|c|}
\hline Bryozoan & Bare & Barnacle & Annelida & Bryozoan & Mollusc & Silt & Slime \\
\hline 1 & 11 & 13 & 0 & 3 & 16 & 2 & 4 \\
\hline 0 & 5 & 17 & 2 & 7 & 10 & 4 & 5 \\
\hline 4 & 3 & 11 & 1 & 5 & 18 & 0 & 8 \\
\hline 0 & 1 & 8 & 1 & 9 & 17 & 6 & 8 \\
\hline 1 & 5 & 8 & 7 & 7 & 13 & 4 & 5 \\
\hline 0 & 13 & 8 & 2 & 3 & 19 & 2 & 3 \\
\hline
\end{tabular}

